\title{
The Portrayal of a Nature-Human Relationship in Aranyaka: Book of the Forest
}

\author{
Cynthiya Rose J S and Bhuvaneswari R \\ School of Social Sciences and Languages, Vellore Institute of \\ Technology, Vandalur, Chennai, Tamilnadu, India \\ Corresponding author email: rosecynthiya@gmail.com
}

\section{ABSTRACT}

The nature-human relationship has been a debating topic in contemporary research, as the relationship with nature differs from man to woman. Also, the nature-human bond evolves or devolves over time. Thus, a tiny change in human behaviour causes catastrophic changes in nature. The research paper differentiates the responsibilities, desires and capabilities of humans over nature, through Amruta Patil and Devdutt Pattanaik's Aranyaka: Book of the Forest, a graphic novel. Actor-Network Theory (ANT) is applied to link and differentiate gender-based interactions with nature. Overall, the analysis picturises the bond between nature and humans aside from tiny gender distinctions. This entanglement shows the relevance of graphic novels illustrating and teaching the importance of nature-human interaction to both adults and children alike.

KEY WORDS: NATURE-HUMAN RELATIONSHIP (NATURE, HUMAN), ARANYAKA, GENDER, GRAPHIC NOVELS, ACTORNETWORK THEORY (ANT).

\section{INTRODUCTION}

"We often forget that we are nature. Nature is not something separate from us. So, when we say that we have lost our connection to nature, we've lost our connection to ourselves."- Andy Goldsworthy The naturehuman relationship can be defined as the interaction between nature and humans. Understanding the naturehuman relationship has been a debating research subject and it has uncovered that humans are going beyond the belief of being part of nature (Davis et al., 2009). Humans began to conquer and depend on nature for subsistence, productivity and stability. Their greed for natural resources or elements resulted in a dispute between humans and nature. Several studies in this field have assured that human interaction with nature influences physical health (Seymour, 2016; Nisbet, 2011; Nisbet \&t Zelenski, 2011), psychological well-being (Capaldi et al.,

Biosc Biotech Res Comm P-ISSN: 0974-6455 E-ISSN: 2321-4007

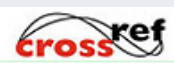

Identifiers and Pagination

Year: 2021 Vol: 14 No (8) Special Issue

Pages: 236-241

This is an open access article under Creative

Commons License Attribn 4.0 Intl (CC-BY).

DOI: $h t t p: / / d x . d o i . o r g / 10.21786 / b b r c / 14.8 .55$
2014; Mayer et al., 2009) and social cohesion (Peters et al., 2010).

Actor-network theory is 'co-constructionis': in the sense that tries to figure out how relation and entity come into being together (Murdoch, 2001). The Actor-Network Theory (ANT), characterized as a theory, "maps the social relations between people, objects and ideas, treating all as agentic entities that form a broad network". It aims to expand the concept of a social network by demonstrating that the social group "consists of patterned networks of heterogeneous materials called actants. An actant is an independent entity that can acquire the ability to make things happen." (Cerulo, 2009). In this research, ANT represents the network's connectivity of nature and human. Network refers to an action that performs continuously or else the network will dissolve. This article builds upon Actor-network theory as an approach to prove the instinctive relationship between nature and humans. It merely focuses on understanding genderspecific interaction with nature.

Amruta Patil and Devdutt Pattanaik's Aranyaka: Book of the Forest substances that humans have an intimate relationship with nature. Aranyaka: Book of the Forest, a graphic novel, can be enjoyed by both adults and children. It is a story about Katyayani, a protagonist who exiles in the forest for eating food that was offered to god. In the

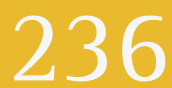


forest she has nothing but food, despite the fact when she met Y, she gave him everything she had (food and sex) to satisfy his appetite. Katyayani, who desired to feed the hunger, left intellectual Y's classroom and preferred the kitchen (her identity) and her grove (nature). Likewise, each character's interaction and intention towards nature vary. In the novel, illustrations of human behaviour and actions are contrasted with animals, to depict the parallel life connectivity. This novel is an affirmation of the natural world and its centrality to non-mainstream value systems and aesthetics. The story can be seen through two lenses that women as a representation of nature as well as forest, a natural environment. The article analyses the bond with nature, by categorising humans into genderspecific and individuals. It also highlights the impact of human interaction with nature in improving physical health, raising awareness of protecting nature.

\begin{tabular}{|c|c|c|c|c|}
\hline S. No & $\begin{array}{l}\text { Davis, J. L., } \\
\text { Green, J. D., \&t } \\
\text { Reed, A. }\end{array}$ & (2009) & $\begin{array}{l}\text { Title } \\
\text { Nature-human Relationship } \\
\text { Interdependence with } \\
\text { the environment: } \\
\text { Commitment, interconnectedness, } \\
\text { and environmental behaviour }\end{array}$ & $\begin{array}{l}\text { Discussion } \\
\text { (aim, method, result) } \\
\text { The paper examines the beliefs } \\
\text { of individuals regarding their } \\
\text { interdependence with the } \\
\text { natural world and its impact on } \\
\text { environmental behaviour. } \\
\text { The study introduces a scale } \\
\text { and uses interdependence theory } \\
\text { to assess the devotion of } \\
\text { people to the natural environment. } \\
\text { The study results in commitment and } \\
\text { interconnectedness with the environment, } \\
\text { a strong predictor of pro-environmental } \\
\text { behaviour (humans are linked with } \\
\text { the natural environment in many ways) }\end{array}$ \\
\hline 2. & $\begin{array}{l}\text { Van der Werff, E., } \\
\text { Steg, L., \&t } \\
\text { Keizer, K. }\end{array}$ & (2013) & $\begin{array}{l}\text { The value of environmental } \\
\text { self-identity: The relationship } \\
\text { between biospheric values, } \\
\text { environmental self-identity and } \\
\text { environmental preferences, } \\
\text { intentions and behaviour }\end{array}$ & $\begin{array}{l}\text { The study shares the link between } \\
\text { biospheric values, environmental } \\
\text { self-identity and environmental } \\
\text { preferences, intentions and behaviour. } \\
\text { The value of environmental } \\
\text { self-identity thoroughly regulated } \\
\text { the connection between biosphere } \\
\text { values and environmental preferences, } \\
\text { intentions, and actions, then indicating } \\
\text { that biosphere values are connected } \\
\text { to preferences, intentions, and } \\
\text { behaviour by one's } \\
\text { environmental self-identity. }\end{array}$ \\
\hline 3. & $\begin{array}{l}\text { Lokhorst, A. M., } \\
\text { Hoon, C., le } \\
\text { Rutte, R., Ct . } \\
\text { de Snoo, G }\end{array}$ & (2014) & $\begin{array}{l}\text { There is an I in nature: } \\
\text { The crucial role of the self } \\
\text { in nature conservation }\end{array}$ & $\begin{array}{l}\text { The paper analyses the social- } \\
\text { psychological determinants of } \\
\text { private nature conservation } \\
\text { through the theory of planned } \\
\text { behaviour that includes } \\
\text { self-identity, place attachment, } \\
\text { and connectedness to nature. } \\
\text { It ensued in findings that both } \\
\text { connectedness to nature and } \\
\text { self-identity impact } \\
\text { environmental intentions. }\end{array}$ \\
\hline 4. & Mohai, P. & (1992) & $\begin{array}{l}\text { Men, Women, and The Environment: } \\
\text { An Examination of The Gender } \\
\text { Gap in Environmental } \\
\text { Concern and Activism }\end{array}$ & $\begin{array}{l}\text { The paper examines the level } \\
\text { of environmental concern and } \\
\text { activism by evidencing national } \\
\text { survey data which states women's } \\
\text { participation in environmental }\end{array}$ \\
\hline
\end{tabular}




\begin{tabular}{|c|c|c|c|c|}
\hline & & & & $\begin{array}{l}\text { activism as a comparatively less than } \\
\text { environmental concern. Thus, this } \\
\text { research emphasizes that before } \\
\text { and after applying multivariate } \\
\text { controls for age, labour force/ } \\
\text { homemaker status, education, and } \\
\text { other factors, women show } \\
\text { greater concern for } \\
\text { the environment than men. }\end{array}$ \\
\hline 5 & Dunlap, R. E. & $(1983)$ & $\begin{array}{l}\text { Male-Female Differences } \\
\text { in Concern for } \\
\text { Environmental Quality }\end{array}$ & $\begin{array}{l}\text { The study explores the association } \\
\text { between sex and environmental concern, } \\
\text { using several multi-item scales } \\
\text { to measure concern for specific } \\
\text { environmental issues such as } \\
\text { pollution control and resource } \\
\text { conservation. This has resulted in } \\
\text { women being more concerned } \\
\text { about environmental quality than men. }\end{array}$ \\
\hline 6. & $\begin{array}{l}\text { Capaldi, C. A., } \\
\text { Dopko, R. L., \&t } \\
\text { Zelenski, J. M. }\end{array}$ & (2014). & $\begin{array}{l}\text { The Relationship between } \\
\text { Nature Connectedness and } \\
\text { Happiness: A Meta-Analysis }\end{array}$ & $\begin{array}{l}\text { Meta-analysis is undertaken to } \\
\text { explore the relationship between } \\
\text { connectedness with nature } \\
\text { and happiness. The findings } \\
\text { suggest that happiness doesn't } \\
\text { come from the effect of } \\
\text { closer relationships between man } \\
\text { and nature; rather, it is suggested } \\
\text { that happiness is not } \\
\text { an impact but intertwined. }\end{array}$ \\
\hline 7. & Seymour, V. & (2016) & $\begin{array}{c}\text { The Human-Nature Relationship } \\
\text { and Its Impact on Health: } \\
\text { A Critical Review }\end{array}$ & $\begin{array}{c}\text { The study attempts to explain } \\
\text { an evolving relationship between } \\
\text { human- nature and its effect } \\
\text { on the wellbeing of people. } \\
\text { The thesis emphasizes the close } \\
\text { human-nature connection } \\
\text { that contributes to a healthier well-being. }\end{array}$ \\
\hline 8. & Momsen, J. H. & (2000). & $\begin{array}{l}\text { Gender Differences in } \\
\text { Environmental Concern } \\
\text { and Perception }\end{array}$ & $\begin{array}{l}\text { The paper aims at exploring } \\
\text { the impact of gender on } \\
\text { environmental politics. It explores } \\
\text { that women have a unique } \\
\text { relationship with nature through } \\
\text { field data analysis. }\end{array}$ \\
\hline \multirow[t]{2}{*}{9.} & $\begin{array}{c}\text { Gough, A., \&t } \\
\text { Whitehouse, H. }\end{array}$ & (2019). & $\begin{array}{l}\text { Centering Gender on the } \\
\text { Agenda for Environmental } \\
\text { Education research }\end{array}$ & $\begin{array}{l}\text { This article tracks the history } \\
\text { of feminist environmental } \\
\text { education research in environmental } \\
\text { research journals and reveals } \\
\text { that it does not entirely focus } \\
\text { on the climate crisis within the } \\
\text { turf but also touches on gender equality. }\end{array}$ \\
\hline & & & Actor-Network Theory (ANT) & \\
\hline 10 & Whatmore, S. & (2002). & $\begin{array}{l}\text { Hybrid Geographies: } \\
\text { Natures Cultures Spaces }\end{array}$ & $\begin{array}{l}\text { A pioneering text for the } \\
\text { reconceptualization of the } \\
\text { nature-human bond. It explains } \\
\text { more than human geography, } \\
\text { how nature and humans are } \\
\text { intertwined. The Style of the }\end{array}$ \\
\hline
\end{tabular}




\begin{tabular}{|c|c|c|c|c|}
\hline & & & & $\begin{array}{l}\text { book echoes 'open-endedness' and } \\
\text { 'on becoming', which differ from } \\
\text { conventional monographs. With its } \\
\text { hybridity and distributed } \\
\text { agency ideas, ANT serves as } \\
\text { an important inspiration. }\end{array}$ \\
\hline 11 & Hitchings, R. & (2003). & $\begin{array}{l}\text { People, Plants and Performance: } \\
\text { On Actor Network Theory and } \\
\text { the Material Pleasures of } \\
\text { the Private Garden }\end{array}$ & $\begin{array}{l}\text { A significant paper that refers } \\
\text { to the criticism of early ANT } \\
\text { as Machiavellian in analysing } \\
\text { the pleasures and emotions } \\
\text { involved with the private gardens } \\
\text { of individuals. It explains how } \\
\text { the power locus oscillates } \\
\text { between gardeners and plants. }\end{array}$ \\
\hline 12. & Hinchliffe, S & (2007) & $\begin{array}{l}\text { Geographies of Nature: } \\
\text { Societies, Environments, } \\
\text { Ecologies }\end{array}$ & $\begin{array}{l}\text { This book culminates in a plea } \\
\text { for adopting a Latour-style } \\
\text { view of hybrid natures, or } \\
\text { multilateralism, across different } \\
\text { understandings of nature. } \\
\text { A counterweight to the interpretation } \\
\text { of nature by social constructivists } \\
\text { (which it also covers). } \\
\text { Adequate for advanced learners. }\end{array}$ \\
\hline 13. & Murdoch, J. & (1997). & $\begin{array}{l}\text { Inhuman/Nonhuman/Human: } \\
\text { Actor-Network Theory and the } \\
\text { Prospects for a Nondualistic and } \\
\text { Symmetrical Perspective } \\
\text { on Nature and Society }\end{array}$ & $\begin{array}{l}\text { A plea against anthropocentric } \\
\text { social science, involving ANT's } \\
\text { assistance in raising dualisms } \\
\text { between people and nature/technology. } \\
\text { The excellent introduction (and not just } \\
\text { for geographers) also considers } \\
\text { ANT criticism and how to respond to it. }\end{array}$ \\
\hline 1. & Murdoch, J. & (2001). & $\begin{array}{l}\text { Ecologising Sociology: } \\
\text { Actor-Network Theory, } \\
\text { Co-Construction and the } \\
\text { Problem of Human Exemptionalism }\end{array}$ & $\begin{array}{l}\text { The study addresses the traditional } \\
\text { division between nature and society } \\
\text { which is specified by ecology that } \\
\text { natural and social entities are bound } \\
\text { together in complex interrelations. } \\
\text { By focusing on ANT as 'a } \\
\text { co-constructionist', the article resulted } \\
\text { in framing both human and nonhuman } \\
\text { within the single reference, even } \\
\text { though the general differences } \\
\text { occurred between the two. }\end{array}$ \\
\hline
\end{tabular}

Literature Review: The relationship between nature and man is presented through a comprehensive literature review. The review summarises and surveys scholarly articles, books, and other sources. It critically analyses the interconnectedness between human and nonhuman (nature) and Actor-Network Theory (ANT) as the theoretical basis for the study.

\section{METHODOLOGY}

Amruta Patil and Devdutt Pattanaik's, "Aranyaka: Book of the Forest" is analysed using the textual analysis method. Actor-Network Theory (ANT) as a theoretical framework depicts the construction of a network mechanism between nature and humans. Research articles, books and other sources related to the nature- human relationship and actor-network theory are reviewed and organized thematically.

Gender-Specific Interaction Towards Nature In Aranyaka: Actor-Network Theory (ANT), which was developed by the sociologist Bruno Latour, Michel Callon and John law in the early 1980s, emerged from Science and Technology Studies (STS) in Geography. According to ANT, all the entities are equal. The fundamental base for this article is ANT from Whatmore's (2002) outcome concept, "how nature and humans are intertwined'. It builds upon expanding the 'human' into gender-specific interaction. Theorists assert the existence of a unique relationship between nature and humans. Theoretical explanations of gender-specific relationships with nature reveal that women are closer and more concerned about nature 
than men (Momsen, 2000; Mohai, 1992; Dunlap, 1983). It is probably due to women's 'motherhood mentality' and men's 'marketplace mentality' (Mohai, 1992). In Aranyaka, Katyayani, Maitreyi and Fig are compared to 'the three flowing rivers' (Patil \& Pattanaik, 2019, p. 123,139). Throughout history, women have been compared to nature. In India, rivers like Kaveri, Narmada, Ganga, Sindhu have female names. Susan Farlow's (2011) "Sex and the river - male or female waterways" pins that the productive and feeding nature of rivers becomes the reason for their female names.

The relationship with nature can be understood from the concept of biophilia which is coined by Harvard naturalist Dr. Edward 0. According to his Biophilia (1987), biophilia is about "the urge to affiliate with other forms of life' (Kellert, 1995, p. 416). Humans have an innate and inherent connection with nature, which is imprinted in human DNA. The novel also implies "When you open your eyes as wide as the god's - you see humans in Aranya and Aranya in humans. That's all" (Patil \& Pattanaik, 2019, p. 90). Human interactions with nature, however, vary due to individual divergences (Seymour, 2016). Aranyaka explores the way each character reacts to nature. Katyayani the large, protagonist of the story is completely enamoured with nature, "you see my fears. You offer me relief” (Patil \& Pattanaik, 2019, p. 25). Her bond with nature led her to share emotions in the grove where she found real peace and joy. Y (Yajnavalkya), Katyayani's husband who ignores nature in favour of wisdom (intelligence), says "you can kill a tree unsubtly or subtly. You can over-water it till the roots out, or starve it slowly. You can kill it with flame or axe or poison at the roots" (Patil \& Pattanaik, 2019, p. 49).

Two other primary women characters, Gargi the Weaver, prefers wisdom - "but like all animals, she saw only opportunity or threat” (Patil \& Pattanaik, 2019, p. 107); and Maitreyi the Fig, appreciates both nature and wisdom - "her Aranya with its scant vegetation and rugged rock faces had no resemblance to the dark, wet Aranya I knew. She saw my forest as a source of esoteric knowledge and was curious - ... she would've liked me to intellectualise Aranya, ... She'd have liked me to romanticise it," (Patil Et Pattanaik, 2019, p. 121). Upakoshala, Uppi who left her wife and came to Y for learning, acknowledges the true wisdom taught by nature, so he admitted, "I judged her harshly for not being me. I must go back now. My big lesson came from the kitchen, not from the classroom" (Patil \& Pattanaik, 2019, p. 99). He also recognized the importance of human's need for nature, "the cows didn't really need him, he needs them" (Patil \&t Pattanaik, 2019, p. 97).

In this contemporary era, humans find solace in intellectual technology so that their focus on nature is altered. It increases human hegemony over nature (Martin et al., 2016). In Aranyaka, Katyayani calls herself 'Aranyani', "one hears of aranyanis like me, women who contain aranya within them" (Patil \& Pattanaik, 2019, p. 122). Thus, in this part of the analysis, Katyayani is taken as a representation of nature. Similarly, Y and
M (Fig) are human and intellectual representations, respectively. Katyayani tends to feed the hunger with compassion rather than aggression. Even she (nature) offered Y(human) everything she has, sex ["flowers are about sex and sex only"] (Patil \& Pattanaik, 2019, p. 118)] and food. On the other hand, Y deserted her and preferred M. Likely, even though nature offers everything, humans are likely to take advantage of it.

Katyayani sees both herself and Y as equal, "I (nature) thought we were equals, bilateral symmetry of leaves. He (human), the fire of enlightenment. And me (nature), the fire of the microcosm" (Patil \&t Pattanaik, 2019, p. 93). But, "Y (human) thought we were halves, not equals. He, above. Me, below” (Patil \& Pattanaik, 2019, p. 93). Finally, while Fig begins her journey with Y, she chooses to be with Katyayani, "who feeds the one who feeds everyone? I (intellectual) must return to hold the ladle to Katyayani's (nature) lip. Allow me to go, Y(human)" (Patil \& Pattanaik, 2019, p. 157). Thus, the paper identifies that intelligence is shaped by the successful interaction between nature and humans.

\section{CONCLUSION}

The study analysis reveals Aranyaka: Book of the Forest as an epitome of man's life with nature from the basic concept of Actor-network theory (ANT) which leads to a detailed look at gender-specific bond towards nature. Contrasting to the several studies that shown women are more concerned about nature, the present analysis explores each individual's interaction is different and it does not depend on gender. Katyayani, Maitreyi and Fig belong to the same gender but their responses toward nature differ. The study further emphasizes that knowledge and morals do not just gather inside the four walls of the classroom but also through human interaction with nature just like the protagonist Katyayani learned from nature. Beyond the spectrum, the study projects the similarity between humans and nature, and also the impact of nature on human life.

Besides, illustrations in these graphic novels easily sow the thought of nature and humans as equal in children's minds that results in a profound effect on the holistic physical and psychological well-being of the adult. Novel's green narratives present the strong message that without nature humans are nothing, and the connectivity makes a human complete. This novel provokes us to think in a bio-centric way. Hence, further research can be done from the ecological, eco-feminist, animal studies, and cultural studies perspectives. It will be helpful to rethink nature and understand more from nature's perspective for a better relationship with humans.

\section{REFERENCES}

Capaldi, C. A., Dopko, R. L., \& Zelenski, J. M. (2014). The Relationship Between Nature Connectedness and Happiness: A Meta-Analysis. Frontiers in Psychology, 5, 976.

Cerulo, K. A. (2009). Nonhumans in Social Interaction. 
Annual Review of Sociology, 35, 531-552.

Davis, J. L., Green, J. D., \&t Reed, A. (2009). Interdependence with The Environment: Commitment, Interconnectedness, and Environmental Behavior. Journal of Environmental Psychology, 29(2), 173180.

Dunlap, R. E. (1983). Male-Female Differences in Concern for Environmental Quality. International Journal of Women's Studies, 6(4).

Gough, A., \& Whitehouse, H. (2019). Centering Gender on The Agenda for Environmental Education Research. The Journal of Environmental Education, 50(4-6), 332347.

Hinchliffe, S. (2007). Geographies of Nature: Societies, Environments, Ecologies. Sage.

Hitchings, R. (2003). People, Plants and Performance: On Actor Network Theory and The Material Pleasures of The Private Garden. Social \& Cultural Geography, 4(1), 99-114.

Kellert, S. R. (1995). The Biophilia Hypothesis. Island Press.

Lokhorst, A. M., Hoon, C., Le Rutte, R., \& De Snoo, G. (2014). There is an I in nature: The crucial role of the self in nature conservation. Land Use Policy, 39, 121126.

Mayer, F. S., Frantz, C. M., Bruehlman-Senecal, E., \&t Dolliver, K. (2009). Why Is Nature Beneficial? The Role of Connectedness to Nature. Environment and Behavior. 41, 607-643.

Mohai, P. (1992). Men, Women, and The Environment: An Examination of The Gender Gap in Environmental Concern and Activism. Society \& Natural Resources, 5(1), 1-19.

Momsen, J. H. (2000). Gender Differences in
Environmental Concern and Perception. Journal of Geography, 99(2), 47-56.

Murdoch, J. (1997). Inhuman/Nonhuman/Human: Actor-Network Theory and The Prospects for A NonDualistic and Symmetrical Perspective on Nature and Society. Environment and Planning D: Society and Space, 15(6), 731-756.

Murdoch, J. (2001). Ecologising Sociology: ActorNetwork Theory, Co-Construction and The Problem of Human Exemptionalism. Sociology, 35(1), 111-133.

Nisbet, E. K. (2011). A Nature Relatedness Intervention to Promote Happiness and Environmental Concern. Unpublished doctoral thesis, Carleton University, Ottawa, ON.

Nisbet, E. K., \& Zelenski, J. M. (2011). Underestimating Nearby Nature: Affective Forecasting Errors Obscure the Happy Path to Sustainability. Psychological Science, 22, 1101-1106.

Patil, A., \&t Pattanaik, D. (2019). Aranyaka: Book of the Forest. Chennai: Tranquebar.

Peters, K., Elands, B., \&t Buijs, A. (2010). Social Interactions in Urban Parks: Stimulating Social Cohesion?. Urban Forestry \&t Urban Greening, 9(2), 93-100.

Seymour, V. (2016). The Human-Nature Relationship and Its Impact on Health: A Critical Review. Frontiers in Public Health, 4, 260.

Van der Werff, E., Steg, L., \& Keizer, K. (2013). The Value of Environmental Self-Identity: The Relationship between Biospheric Values, Environmental SelfIdentity and Environmental Preferences, Intentions and Behaviour. Journal of Environmental Psychology, 34, 55-63.

Whatmore, S. (2002). Hybrid Geographies: Natures Cultures Spaces. Sage. 